\title{
EVALUATION OF IN VITRO ANTIOXIDANT ACTIVITY OF A MEDICINAL HERB, WEDELIA CHINENSIS (OSBECK) MERRILL.
}

\author{
REHANA BANU H ${ }^{1 *}$, NAGARAJAN N² \\ ${ }^{1}$ Department of Botany, PSGR Krishnammal College for Women, Coimbatore - 641 004, Tamil Nadu, India. ${ }^{2}$ Department of Botany \\ Kongunadu Arts and Science College, Coimbatore - 641 029, Tamil Nadu, India. Email: rehanabanu@psgrkc.ac.in
}

Received: 29 January 2018, Revised and Accepted: 30 June 2018

\section{ABSTRACT}

Objective: The objective is to evaluate the antioxidant activity of the methanolic leaf extract of Wedelia chinensis.

Methods: In vitro antioxidant activity was evaluated by studying 1,1-diphenyl-2-picrylhydrazyl (DPPH) radical scavenging activity, superoxide radical scavenging activity, ferric reducing ability of plasma (FRAP) scavenging activity, hydroxyl radical scavenging activity, metal chelating activity, and total antioxidant activity. Ascorbic acid, BHT, quercetin, and EDTA were used as standards for the experiments.

Results: Inhibition concentration ${ }_{50}$ values observed for DPPH radical scavenging, superoxide radical scavenging, and hydroxyl radical scavenging activities were determined to be $62.5,769.23$, and $617.28 \mu \mathrm{g} / \mathrm{ml}$, respectively and that of FRAP scavenging, metal chelating, and total antioxidant activities were found to be $343 \mu \mathrm{mol} F$ (II)/g, $79.56 \mathrm{mg}$ EDTA/g extract, and $398.17 \mathrm{mg}$ ascorbic acid eq/g extract, respectively.

Conclusion: The results clearly indicate that methanolic leaf extract of the study species $W$. chinensis is effective in scavenging free radicals and has the potential to be a powerful antioxidant.

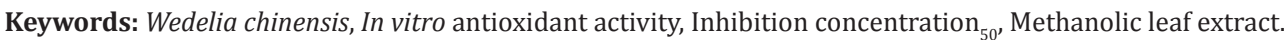

(C) 2018 The Authors. Published by Innovare Academic Sciences Pvt Ltd. This is an open access article under the CC BY license (http://creativecommons. org/licenses/by/4. 0/) DOI: http://dx.doi.org/10.22159/ajpcr.2018.v11i10.25008

\section{INTRODUCTION}

Free radicals may be defined as any chemical species that are capable of existing with one or more unpaired outer shell electrons. They are extremely reactive and generally highly unstable [1]. They are produced endogenously during cellular metabolisms in all forms of aerobic living system, in addition to exogenous sources such as environmental pollutants, drug, radiation, and pathogens [2]. The imbalance between production of reactive oxygen species (ROS) such as $\mathrm{O}_{2} ; \mathrm{H}_{2} \mathrm{O}_{2}, \mathrm{OH}^{-}$, and $\mathrm{ROO}^{-}$and the capacity of the normal detoxification system in favor of the oxidants leads to oxidative stress, which itself lead to cellular damage caused by the interaction of ROS with cellular constituents and several types of biological damages: DNA damage, carcinogenesis, and cellular degeneration $[3,4]$. Tissue damage resulting from oxidative stress has been implicated in the pathology of a number of disorder diseases such as cancer, inflammatory joint disease, cardiovascular diseases, arthritis, and cataract and could play a role in neurodegenerative diseases and aging processes $[5,6]$

Antioxidants are considered as possible protective agents providing protection of living organisms from damage caused by uncontrolled production of ROS and the concomitant lipid peroxidation, protein damage, and DNA-strand breakage [7,8]. Natural antioxidants have a wide range of biochemical activities, including direct or indirect scavenging of free radicals that are released during the normal metabolic process of oxidation such as reactive oxygen free radical species [9]. In the recent years, food scientists and nutrition specialists agree that antioxidant-enriched fruits and vegetables consumed daily contribute to the reduction in risks of certain diseases including cancer and cardiovascular diseases $[10,11]$.

The plant species, Wedelia chinensis selected for the present investigation is a perennial herb of family Asteraceae, commonly known as "Pilabhamgara" or "Bhringraj" in Hindi, Wedelia in Chinese, and "Manjalkarisalanganni" in Tamil [12]. Conventionally, the fruits, leaves, and stem are used in child birth and in the treatment of bites and stings, fever, and infection. The leaves are used in the treatment of kidney dysfunction, cold, wounds, and amenorrhea [13]. However, information pertaining to the antioxidant properties of $W$. chinensis is meager. Hence, in the present study, the possible antioxidant activity of this plant was investigated in detail by employing six different in vitro antioxidant models.

\section{METHODS}

\section{Plant material and extraction}

W. chinensis (Osbeck) Merrill leaves were collected from Attakatti Hills, India. The plant material was taxonomically identified by Dr. V. Balasubramanian, Associate Professor, Department of Botany, Kongunadu Arts and Science College, Coimbatore, Tamil Nadu, India, and was deposited the college herbarium for future reference. For extraction, about $50 \mathrm{~g}$ of the shade dried and powdered leaf material was taken. The powdered material was transferred into $250 \mathrm{ml}$ quick fit flask and extracted in the Soxhlet extractor for $48 \mathrm{~h}[14,15]$ using of organic solvents, namely, petroleum ether, chloroform, ethyl acetate, and methanol separately according to the increasing polarity of the solvents. The extract was filtered over Whatman no. 1 filter paper, and the filtrate was concentrated under reduced pressure to pasty mass [16] for further studies.

\section{Chemicals}

All the chemicals used in the work were purchased from HiMedia Pvt., Ltd., Mumbai. The chemicals used were of analytical grade.

\section{Determination of antioxidant activity}

The antioxidant activity was evaluated by six methods which are as follows:

\section{1,1-diphenyl-2-picrylhydrazyl (DPPH) radical scavenging activity} The DPPH assay measures hydrogen atom (or one electron) donating activity and hence provides a measure of free-radical scavenging antioxidant activity. Free-radical scavenging capacity was evaluated on 
the basis of the scavenging activity of DPPH by measuring the reduction of absorbance at $517 \mathrm{~nm}$. The method was carried out as described by Brand-Williams et al. [17]. Crude methanol extract of $W$. chinensis was redissolved in methanol, and various concentrations $(10,50,100$, 500 , and $2000 \mu \mathrm{g} / \mathrm{mL}$ ) of extract were prepared. The assay mixture contained in a total volume of $1 \mathrm{~mL}$ consists of $500 \mu \mathrm{L}$ of the extract, $125 \mu \mathrm{L}$ of freshly prepared DPPH solution ( $1 \mathrm{mM}$ in methanol), and $375 \mu \mathrm{L}$ of solvent (methanol). The contents were mixed vigorously in a vortex mixer for $10 \mathrm{~s}$ and incubated at room temperature in the dark (wrapped with aluminum foil) for $30 \mathrm{~min}$. The absorbance was read at $517 \mathrm{~nm}$ using a spectrophotometer. In each experiment, the tested sample alone in methanol was used as blank while the DPPH solution alone in methanol was used as control. All experiments were carried out in triplicate. Ascorbic acid was used as standard. The results were expressed as percentage inhibition.

The DPPH radical scavenging activity was calculated using the formula:

$\%$ inhibition $=[($ A control $-\mathrm{A}$ sample $) / \mathrm{A}$ control $] \times 100$

where A control and A sample are the absorbance values of the control and test sample, respectively.

\section{Superoxide radical scavenging activity}

Superoxide radical generated from the photoreduction of riboflavin was detected by nitro blue tetrazolium reduction method Beauchamp and Fridovich [18]. Each $3 \mathrm{ml}$ of reaction mixture contained $50 \mathrm{mM}$ phosphate buffer ( $\mathrm{pH}$ 7.8), $13 \mathrm{mM}$ methionine, 2 IM riboflavin, 100 IM EDTA, NBT (75 lM), and $1 \mathrm{ml}$ of sample solution. The tubes were illuminated under incandescent lamp for $15 \mathrm{~min}$. The production of blue formazan was followed by monitoring the increase in absorbance at $560 \mathrm{~nm}$ after $10 \mathrm{~min}$ of illumination from a fluorescent lamp. The inhibition of superoxide radical generation was determined by comparing the absorbance values of the control (phosphate buffer as blank) with that of the treatments. BHT and quercetin were used as reference materials.

The superoxide radical scavenging activity was calculated using the formula:

$\%$ inhibition $=[($ A control $-\mathrm{A}$ sample $) / \mathrm{A}$ control $] \times 100$

where A control and A sample are the absorbance values of the control and test sample, respectively.

\section{Ferric reducing ability of plasma (FRAP) scavenging activity}

The ferric reducing capacity of the extract was measured based on the ferric reducing activity assay (FRAP) [19]. FRAP reagent was prepared by mixing $2.5 \mathrm{~mL}$ of solution ferric trichloride hexahydrate $(20 \mathrm{mM})$, $2.5 \mathrm{~mL}$ of solution (2,4,6-tripyridyl-s-triazine) TPTZ (10 mM in $40 \mathrm{mM}$ of hydrochloric acid), and $25 \mathrm{~mL}$ of acetate buffer $0.3 \mathrm{M} \mathrm{(pH} \mathrm{3.6)} \mathrm{and}$ incubating at $37^{\circ} \mathrm{C}$. The extract was dissolved in methanol to yield a final concentration (w/v) of $1 \mathrm{mg} / \mathrm{mL}$. For each analysis, $30 \mu \mathrm{L}$ of methanolic solution was added to $180 \mu \mathrm{L}$ of distilled water and $1.8 \mathrm{~mL}$ of FRAP solution. The increase of absorbance was recorded at $593 \mathrm{~nm}$, during $30 \mathrm{~min}$ at $37^{\circ} \mathrm{C}$. The standard curve was constructed using $\mathrm{FeSO}_{4} \cdot 7 \mathrm{H}_{2} \mathrm{O}$ solution, and the results were expressed as $\mu \mathrm{mol} F e(\mathrm{II}) / \mathrm{g}$ dry weight of plant material.

\section{Hydroxyl radical scavenging activity}

The hydroxyl radical scavenging activity was determined according to the method of Klein et al [20]. Various concentrations of plant extract in methanol were placed in different test tubes and evaporated. One $\mathrm{ml}$ of iron-EDTA solution (0.13\% ferrous ammonium sulfate and $0.26 \%$ EDTA), $0.5 \mathrm{ml}$ of EDTA $(0.018 \%)$, and $1 \mathrm{ml}$ of DMSO $(0.85 \% \mathrm{v} / \mathrm{v}$ in $0.1 \mathrm{M}$ phosphate buffer, $\mathrm{pH}$ 7.4) were added to these tubes, and the reaction was initiated by adding $0.5 \mathrm{ml}$ of $0.22 \%$ ascorbic acid. Test tubes were capped tightly and heated on a water bath at $80-90^{\circ} \mathrm{C}$ for $15 \mathrm{~min}$. The reaction was terminated by the addition of ice-cold trichloroacetic acid $(17.5 \% \mathrm{w} / \mathrm{v})$. Three milliliters of Nash reagent $(75.0 \mathrm{~g}$ of ammonium acetate, $3 \mathrm{ml}$ of glacial acetic acid, and $2 \mathrm{ml}$ of acetylacetone were mixed and raised to $1 \mathrm{~L}$ with distilled water) was added to all the tubes, and the tubes were allowed to stand at room temperature for $15 \mathrm{~min}$ for color development. Intensity of the yellow color formed was measured at $412 \mathrm{~nm}$ against reagent blank. Quercetin and BHT were used as reference standards. Percentage hydroxyl radical scavenging was calculated by the following formula:

Hydroxyl radical scavenging activity (\%) = 1 - (difference in absorbance of sample/difference in absorbance of blank $) \times 100$

\section{Metal chelating activity}

The chelation of ferrous ions by the plant extract and standards was estimated by the method of Dinis et al. [21]. Aliquots ( $1 \mathrm{ml})$ of the plant extract dissolved in the same solvents at concentrations of 0 (control), $1,2.5$, and $5 \mathrm{mg} / \mathrm{ml}$ were separately added to $2.8 \mathrm{ml}$ of distilled water, followed by mixing with $50 \mu \mathrm{l}$ of $2 \mathrm{mM} \mathrm{FeCl}_{2} \cdot 4 \mathrm{H}_{2} \mathrm{O}$ and $150 \mu \mathrm{l}$ of $5 \mathrm{mM}$ ferrozine. The mixtures were then shaken vigorously and left standing at room temperature for $10 \mathrm{~min}$. Absorbance levels of the solutions were measured using a spectrophotometer at $562 \mathrm{~nm}$. All tests and analyses were run in triplicate and averaged. The percentage of inhibition of ferrozine - $\mathrm{Fe}^{2+}$ complex formation was calculated using the formula given below:

Chelating activity $(\%)=[(\mathrm{A} 0-\mathrm{A} 1) / \mathrm{A} 0] \times 100$

Where A0 is the absorbance of the control and A1 is the absorbance in the presence of the plant extract. EDTA was used as a reference compound.

\section{Total antioxidant activity}

Total antioxidant capacity of extract was estimated as described by Prieto et al. [22]. An aliquot of $0.1 \mathrm{ml}$ of extract was mixed with $1 \mathrm{ml}$ of phosphomolybdenum reagent solution (0.6 M sulfuric acid, $28 \mathrm{mM}$ sodium phosphate, and $4 \mathrm{mM}$ ammonium molybdate) and $1.8 \mathrm{ml}$ of distilled water in an Eppendorf tube. The tubes were capped and incubated at $95^{\circ} \mathrm{C}$ for $90 \mathrm{~min}$. After the samples had cooled to room temperature, the absorbance of each was measured at $695 \mathrm{~nm}$ against a reagent blank. Gallic acid was used as standard $(0.02-0.1 \mathrm{mg} / \mathrm{ml})$, and transport accident commission was estimated as mg GAE/g dried extract from calibration curve given by equation $\mathrm{y}=0.006 \mathrm{x}+0.102$ $\left(\mathrm{R}^{2}=0.93\right)$.

\section{Inhibition concentration ${ }_{50}\left(\mathrm{IC}_{50}\right)$}

$\mathrm{IC}_{50}$ was introduced and interpreted by Brand-Williams et al. [17]. The discoloration of sample was plotted against the sample concentration to calculate the $\mathrm{IC}_{50}$ value. It is defined as the amount of sample necessary to decrease the absorbance of the radical by $50 \%$.

\section{RESULTS}

The level of free-radical scavenging activity through DPPH method, superoxide radical scavenging activity, and hydroxyl radical scavenging activity of methanol leaf extract of $W$. chinensis is depicted in Tables 1-3.

\section{DPPH radical scavenging activity}

The assay of the scavenging of 1,1-diphenyl 2-picrylhydrazyl (DPPH) radical is widely used as the model system to investigate the scavenging activities of several natural compounds such as crude mixtures or solvent extract of plants [23]. The principle of DPPH assay is that the antioxidant reacts with the stable free-radical DPPH (deep violet color) and converts it to DPPH with a yellow color. The degree of discoloration indicates the scavenging potential of the sample antioxidant [24], resulting in a decrease in absorbance at $517 \mathrm{~nm}$.

The methanolic extract of $W$. chinensis quenched DPPH radicals in a dose-dependent manner. The percentage of scavenging effect on the 
Table 1: DPPH scavenging efficiency of methanol leaf extract of $W$. chinensis

\begin{tabular}{|c|c|c|c|c|}
\hline \multirow[t]{2}{*}{ Concentration $(\mu \mathrm{g} / \mathrm{ml})$} & \multicolumn{4}{|c|}{ \% DPPH inhibition } \\
\hline & Extract & $I C_{50}(\mu \mathrm{g} / \mathrm{ml})$ & Ascorbic acid & $\mathrm{IC}_{50}(\mu \mathrm{g} / \mathrm{ml})$ \\
\hline 1000 & 77.25 & & 98.01 & \\
\hline 500 & 70.23 & & 97.20 & \\
\hline 250 & 69.52 & & 96.3 & \\
\hline 125 & 65.23 & & 90.34 & \\
\hline 62.5 & 52.85 & 31.25 & 89.32 & 3.906 \\
\hline 31.25 & 49.56 & & 83.56 & \\
\hline 15.625 & 45.23 & & 77.40 & \\
\hline 7.8125 & 34.58 & & 71.45 & \\
\hline 3.906 & 23.63 & & 68.32 & \\
\hline Cell control & 100 & & 100 & \\
\hline
\end{tabular}

DPPH: 1,1-diphenyl-2-picrylhydrazyl, $\mathrm{IC}_{50}$ : Inhibition concentration50, W. chinensis: Wedelia chinensis

Table 2: Superoxide radical scavenging activity of methanol extract of $W$. chinensis

\begin{tabular}{|c|c|c|c|c|c|c|}
\hline \multirow[t]{2}{*}{ Concentration $(\mu \mathrm{g} / \mathrm{ml})$} & \multicolumn{6}{|c|}{ Superoxide radical scavenging activity } \\
\hline & Extract & $\mathrm{IC}_{50}(\mu \mathrm{g} / \mathrm{ml})$ & BHT & $\mathrm{IC}_{50}(\mu \mathrm{g} / \mathrm{ml})$ & Quercetin & $\mathrm{IC}_{50}(\mu \mathrm{g} / \mathrm{ml})$ \\
\hline 100 & $7.85 \pm 0.68$ & & $36.11 \pm 0.04$ & & $32.11 \pm 0.04$ & \\
\hline 200 & $14.76 \pm 0.32$ & & $60.42 \pm 0.02$ & & $49.42 \pm 0.02$ & \\
\hline 300 & $20.81 \pm 0.64$ & 769.23 & $66.55 \pm 0.04$ & 105 & $62.06 \pm 0.01$ & 233 \\
\hline 400 & $26.21 \pm 0.53$ & & $75.25 \pm 0.01$ & & $70.48 \pm 0.01$ & \\
\hline 500 & $31.49 \pm 0.63$ & & $90.33 \pm 0.01$ & & $86.42 \pm 0.02$ & \\
\hline
\end{tabular}

$\mathrm{IC}_{50}$ : Inhibition concentration50, W. chinensis: Wedelia chinensis

Table 3: Hydroxyl radical scavenging activity of methanol extract of $W$. chinensis

\begin{tabular}{|c|c|c|c|c|c|c|}
\hline \multirow[t]{2}{*}{ Concentration $(\mu \mathrm{g} / \mathrm{ml})$} & \multicolumn{6}{|c|}{ Hydroxyl radical scavenging activity } \\
\hline & Extract & $\mathrm{IC}_{50}(\mu \mathrm{g} / \mathrm{ml})$ & BHT & $\mathrm{IC}_{50}(\mu \mathrm{g} / \mathrm{ml})$ & Quercetin & $\mathrm{IC}_{50}(\mu \mathrm{g} / \mathrm{ml})$ \\
\hline 100 & $9.25 \pm 1.19$ & & $30.17 \pm 0.042$ & & $29.12 \pm 0.052$ & \\
\hline 200 & $16.51 \pm 0.45$ & & $46.25 \pm 0.048$ & & $45.18 \pm 0.011$ & \\
\hline 300 & $25.67 \pm 1.07$ & 617.28 & $67.42 \pm 0.058$ & 350 & $66.28 \pm 0.011$ & 430 \\
\hline 400 & $32.93 \pm 0.45$ & & $69.42 \pm 0.057$ & & $68.13 \pm 0.012$ & \\
\hline 500 & $39.40 \pm 0.59$ & & $83.38 \pm 0.020$ & & $82.22 \pm 0.013$ & \\
\hline
\end{tabular}

$\mathrm{IC}_{50}:$ Inhibition concentration ${ }_{50}, W$. chinensis: Wedelia chinensis

DPPH radical was increased with the increase in the concentration of leaf extract. The $\mathrm{IC}_{50}$ values were found to be $62.5 \mu \mathrm{g} / \mathrm{ml}$ (plant extract) and $3.906 \mu \mathrm{g} / \mathrm{ml}$ (ascorbic acid), respectively (Table 1).

\section{Superoxide anion scavenging activity}

In the present study, superoxide radical reduced NBT to a blue colored Formosan that was measured at $560 \mathrm{~nm}$ [25]. The relative scavenging effects of the extract and the standards BHT and quercetin toward superoxide anion radicals are shown in Table 2. The plant extract showed moderate superoxide anion scavenging activity as compared to $\mathrm{BHT}$ and quercetin. The $\mathrm{IC}_{50}$ values were found to be 769.23 (plant extract), 105 (BHT), and 233 (quercetin). The percentage inhibition of superoxide radical of plant extract was $7.85 \%(100 \mu \mathrm{g} / \mathrm{ml})$, $14.76 \%(200 \mu \mathrm{g} / \mathrm{ml}), 20.81 \%(300 \mu \mathrm{g} / \mathrm{ml}), 26.21 \%(400 \mu \mathrm{g} / \mathrm{ml})$, and $31.49 \%(500 \mu \mathrm{g} / \mathrm{ml})$. Therefore, the superoxide anion scavenging activity in increasing order was BHT>quercetin $>$ plant extract.

\section{FRAP radical scavenging activity}

The FRAP radical scavenging activity of the extract was $343 \pm 1.7 \mu \mathrm{mol}$ Fe (II)/g. According to the high IC value of the methanolic extract of $W$. chinensis, it could be considered that compounds in the methanolic extract are good electron donors and could terminate oxidation chin reactions by reducing the oxidized intermediates into the stable form [26].
Hydroxyl radical scavenging activity

Table 3 showed that the methanolic leaf extract of $W$. chinensis exhibited concentration-dependent scavenging activity against hydroxyl radicals generated in Fenton reaction. Percentage of inhibition of hydroxyl radical was highest in positive controls of BHT with $83.38 \%$ and quercetin with $82.22 \%$ when compared to plant extract with $39.40 \%$ at $500 \mu \mathrm{g} / \mathrm{ml}$ concentration. The $\mathrm{IC}_{50}$ values of BHT, quercetin, and plant extract were $350 \mu \mathrm{g} / \mathrm{ml}, 430 \mu \mathrm{g} / \mathrm{ml}$, and $617.28 \mu \mathrm{g} / \mathrm{ml}$, respectively. The hydroxyl radical scavenging activity of the extract is due to the freeradical quenching activity of the extract, which can be attributed to the presence of polyphenolics in the extract.

Total antioxidant capacity by phosphomolybdenum method

Total antioxidant capacity by phosphomolybdenum method is based on the reduction of $\mathrm{Mo}(\mathrm{VI})$ to $\mathrm{Mo}(\mathrm{V})$ by antioxidant compounds and subsequent formation of a green phosphate - Mo(V) complex at acidic $\mathrm{pH}$ which has a maximum absorption at $695 \mathrm{~nm}$ [27]. In the present assay, the total antioxidant activity of the leaf methanolic extract of $W$. chinensis was measured and compared with BHT. According to the result, total antioxidant activity increased with increasing concentration. The total antioxidant activity of the extract was $398.17 \pm 3.44 \mathrm{mg}$ ascorbic acid eq/g extract.

Metal chelating activity

The iron-chelating capacity measures the ability of antioxidants to compete with ferrozine in chelating ferrous ion [28]. In this assay, 
ferrozine can complex with ferrous ions, and in the presence of chelating agents, complex (red colored) formation is interrupted; as a result, the red color of the complex decreases [29]. The transition metal ion, $\mathrm{Fe}^{2+}$ possess the ability to move single electrons by virtue, of which it can allow the formation and propagation of many radical reactions, even starting with relatively non-reactive radicals [30]. The formation of the ferrozine - $\mathrm{Fe}^{2+}$ complex is interrupted in the presence of methanol extract of $W$. chinensis, indicating the chelating activity with $\mathrm{IC}_{50}$ of $79.56 \pm 2.55 \mathrm{mg} / \mathrm{g}$ of EDTA. However, $\mathrm{IC}_{50}$ of standard was $76.71 \pm 1.25 \mathrm{~g} / \mathrm{ml}$.

\section{DISCUSSION}

Antioxidants refer to a group of compounds that are able to delay or inhibit the oxidation of lipids or other biomolecules and thus prevent or repair the damage of the body cells that are caused by oxygen [31,32]. They work by preventing the formation of new free-radical species, converting existing free radicals into less harmful molecules and preventing radical-chained reactions [33]. In the present investigation, different antioxidant assays such as DPPH radical scavenging capacity, FRAP assay, metal chelating activity, superoxide radical scavenging activity, hydroxyl radical scavenging activity, and total antioxidant activity by phosphomolybdenum assay were employed to assess the antioxidant effect of the leaf extract of $W$. chinensis. From the study, it is evident that the extract of the study species possesses effective antioxidant activity which may be due to the presence of respective phytochemicals such as flavonoids and phenolics alkaloids, in this species [34].

DPPH radical scavenging is considered to be a good in vitro model widely used to assess antioxidant efficacy within a very short time [35-37]. The relatively stable organic radical, DPPH, has been widely used in the determination of antioxidant activity of single compounds as well as of different plant extracts [38].

The methanolic extract of $W$. chinensis reduced the DPPH radical in a dose-dependent manner. Similar trend of results was displayed in the methanolic leaf extracts of several members of Asteraceae family, namely, Helichrysum chionophilum [39], Centaurea cyanus, Centaurea scabiosa [40], Centaurea calolepis, Centaurea cadmea [41], Vernonia amygdalina [42], Diospyros lotus [43], Hieracium pilosella [44], Chrysanthemum balsamita [45], Centaurea cheirolopha, Centaurea kurdica, Centaurea rigida [46], Helichrysum chasmolycicum [47], Hypericum hookerianum [48], and Stevia rebaudiana [49].

Superoxide anions play important roles in the formation of ROS such as hydrogen peroxide, hydroxyl radical, and singlet oxygen, which induce oxidative damage in lipids, proteins, and DNA [50]. The present study shows that $W$. chinensis possesses superoxide quenching ability. Based on the result, it appears that $W$. chinensis scavenges superoxide radicals by combining with superoxide radical ions to form stable radicals, thus terminating the radical chain reaction [51].

FRAP assay measures the changes in absorbance at $593 \mathrm{~nm}$ owing to the formation of blue colored $\mathrm{Fe}$ - tripyridyltriazine compound from the colorless oxidized Fe form by the action of electron-donating antioxidants [52]. In the present study, the ferric reducing antioxidant power was found to be high in methanolic extract of W. chinensis.

Hydroxyl radicals degrade the sugar deoxyribose (2-deoxy-D-ribose) through Fenton-type reactions leading to the production of complex products which can be estimated as malondialdehyde [53]. The methanolic extract showed minimum activity against hydroxyl radical when compared to that of controls BHA and quercetin.

Total antioxidant activities reflect the capacity of a non-enzymatic antioxidant defence system. In the phosphomolybdenum method, molybdenum VI $\left(\mathrm{Mo}^{6+}\right)$ is reduced to form a green phosphate/ $\mathrm{Mo}^{5+}$ complex at acidic $\mathrm{pHs}$. High absorbance values indicate that the sample possesses significant antioxidant activity. The method is utilized for the spectrophotometric quantitation of total antioxidant capacity and employs cost-effective reagents [22]. The total antioxidant activity of the extract increased with increasing concentration.

The $\mathrm{Fe}^{2+}$ chelating capacity of methanolic extract of $W$. chinensis was determined by measuring the iron-ferrozine complex. The chelating capacity of the extract was found to be higher.

\section{CONCLUSION}

The results of the present study indicate that the methanol leaf extract of $W$. chinensis has significant antioxidant activities which are comparable to that of the standard drugs such as ascorbic acid, BHT, quercetin, and EDTA. It may be related to the presence of phenolic compounds such as flavonoids and tannins because these compounds contain an aromatic hydroxyl moiety. Despite the higher $\mathrm{IC}_{50}$ values of all the six studied antioxidant assays than the standard drug, the leaf extract may be considered as an important source of material for the scavenging of radicals. The high antioxidant activities demonstrated by $W$. chinensis extract suggest that the plant leaves could be a source of potent antioxidant compounds.

\section{ACKNOWLEDGMENTS}

The authors thank the Department of Botany, Kongunadu Arts and Science College, Coimbatore, Tamil Nadu, India, for providing the facilities for the completion of the work.

\section{AUTHOR'S CONTRIBUTIONS}

Both the authors have contributed well in the completion of the above research work.

\section{CONFLICTS OF INTEREST}

The authors declare that they have no conflicts of interest.

\section{REFERENCES}

1. Martínez-Cayuela M. Oxygen free radicals and human disease. Biochimie 1995;77:147-61.

2. Ansari KN. The free radicals - the hidden culprits - an update. Indian J Med Sci 1997;51:319-36.

3. Ozcan MM, Evel O, Herken EE. Antioxidant activity, phenolic content and peroxide value of essential oil and extracts of some medicinal and aromatic plants used as condiments and herbal teas in Turkey. J Med Food 2009;12:198-202.

4. Habila JD, Bello IA, Dzikwi AA, Musa H, Abubakar N. Total phenolics and antioxidant activity of Tridax procumbens Linn. A J Pharm Pharmacol 2010;4:123-6.

5. Halliwell B. Antioxidants and human disease: A general introduction. Nutr Rev 1997;55:S44-9

6. Steer P, Millgård J, Sarabi DM, Basu S, Vessby B, Kahan T, et al. Cardiac and vascular structure and function are related to lipid peroxidation and metabolism. Lipids 2002;37:231-6.

7. Ghosal S, Tripathi VK, Chauhan S. Active constituents of Emblica officinalis: Part I: The chemistry and antioxidant effects of two new hydrolysable tannins, emblicanin A and B. Indian J Chem 1996;35:941-8.

8. Yam MF, Basir R, Asmawi MZ, Ahmad MR, Akowuah GA. Antioxidant and hepatoprotective activities of Elephantopus tomentosus ethanol extract. Pharm Biol 2008:46:199-206.

9. Abdollahi M, Larijani B, Rahimi R, Salari P. Role of oxidative stress in osteoporosis. Therapy 2005;2:787-96.

10. Liu S, Manson JE, Lee IM, Cole SR, Hennekens CH, Willett WC, et al. Fruit and vegetables intake and risk of cardiovascular disease: The women's study. Am J Clin Nutr 2000;72:922-8.

11. Guorong L, Shaohui L, Peng J, Huitong L, Boyi L, Wanhong X, et al. Cerebrovascular blood flow dynamic changes in fetuses with congenital heart disease. Fetal Diagn Ther 2009;25:167-72.

12. Chopra RN. Glossary of Indian Medicinal Plants. New Delhi: Council of Scientific and Industrial Research; 1965. p. 258.

13. Matthew KM. The flora of the Tamil Nadu Carnatic. Tiruchirapalli: The Rapinat Herbarium, St. Joseph's College; 1983. p. 2154.

14. Vaghasiya Y, Nair R, Baluja S, Chanda S. Antibacterial and preliminary 
phytochemical analysis of Eucalyptus citriodora Hk leaf. Nat Prod Rad 2008;22:754-62.

15. Aiyelaagbe OO, Osamudiamen PM. Phytochemical screening for active compounds in Mangifera indica leaves from Ibadan, Oyo State. Plant Sci Res 2009;2:11-3.

16. Yilmaz M, Turk AO, Tay T, Kivanc M. The antimicrobial activity of extract of the lichen Cladonia foliaceaandits (-) Usnic acid, atranorin and fumarprotocetraic acid constituents. Z Naturforsch 2004;59:249-54.

17. Brand-Williams W, Cuevelier ME, Berset C. Use of a free radical method to valuate antioxidant activity. Lebensm Wiss u-Technol 1995;28:25-30.

18. Beauchamp C, Fridovich I. Superoxide dismutase: Improved assays and an assay applicable to acrylamide gels. Anal Biochem 1971;44:276-87.

19. Benzie IF, Strain JJ. The ferric reducing ability of plasma (FRAP) as a measure of "antioxidant power" the FRAP assay. Anal Biochem 1996;239:70-6.

20. Klein SM, Cohen G, Cederbaum AI. Production of formaldehyde during metabolism of dimethyl sulphoxide by hydroxyl radical generating system. Biochemistry 1991;20:6006-12.

21. Dinis TC, Madeira VM, Almeida LM. Action of phenolic derivates acetoaminophen, salicylate and 5-aminosalycilate) as inhibitors of membrane lipid peroxidation and as peroxyl radical scavengers. Arch Biochem Biophys 1994;315:161-9.

22. Prieto P, Pineda M, Aguilar M. Spectrophotometric quantitation of antioxidant capacity through the formation of a phosphomolybdenum complex: Specific application to the determination of Vitamin E1. Anal Biochem 1999;269:337-41.

23. Elmastas M, Gulcin I, Isildak O, Kufrevioglu OI, Ibaoglu K, AboulEnein HY. Radical scavenging activity and antioxidant capacity of Bay leaf extracts. J Iran Chem Soc 2006;3:258-66.

24. Tianpech N, Swatsitang P, Tanpanich S. Antioxidant capacity and nutritional values of Pak-Wanpa (Melientha suavis Pierre.). KKU Sci J 2008;38:75-82

25. Khanamn S, Shivaprasad HN, Kshama D. In vitro antioxidant screening models: A review. Indian J Pharm Educ 2004;38:180-3.

26. Suganya T, Siriporn O, Sombat C. Study on antioxidant activity of certain plants in Thailand: Mechanism of antioxidant action of guava leaf extract. Food Chem 2007; 103:381-8.

27. Saha MR, Hasan SM, Akter R, Hossain MM, Alam MS, Alam MA, et al. In vitro free radical scavenging activity of methanol extract of the leaves of Mimusops elengi Linn. Bangl J Vet Med 2008;6:197-202.

28. Sujata RV, Rathod VS, Yesane DP. Screening of three wild edible fruits for their antioxidant potential. Curr Bot 2011;2:48-52.

29. Nabavi SM, Ebrahimzadeh MA, Nabavi SF, Fazelian M, Eslami B. In vitro antioxidant and free radical scavenging activity of Diospyros lotus and Pyrus boissieriana growing in Iran. Pharmacog Mag 2009a:4:123-7.

30. Aboul-Enein AM, El Baz FK, El-Baroty GS, Youssef AM, Abd El-Baky HH. Antioxidant activity of algal extracts on lipid peroxidation. J Med Sci 2003;3:87-98.

31. Shahidi F, Naczk M. Phenolics in Food and Nutraceuticals. Boca Raton, FL: CRC Press; 2004

32. Tachakittirungrod S, Okonogi S, Chowwanapoonpohn S. Study on antioxidant activity of certain plants in Thailand: Mechanism of antioxidant action of guava leaf extract. Food Chem 2007;103:381-8.

33. Rodríguez J, Olea-Azar C, Cavieres C, Norambuena E, DelgadoCastro T, Soto-Delgado J, et al. Antioxidant properties and free radicalscavenging reactivity of a family of hydroxynaphthalenones and dihydroxyanthracenones. Bioorg Med Chem 2007;15:7058-65.

34. Meena AK, Rao MM, Kaur K, Panda P. Comparative evaluation of standardization parameters between Wedelia genus species. Int J Pharm Sci Res 2010;1:207-10.

35. Oktay M, Gulcin I, Vioglu OI. Determination of in vitro antioxidant activity of fennel Foeniculum vulgare seed extracts. LWT 2003;36:263-71.

36. Shon MY, Kim TH, Sung NJ. Antioxidants and free radical scavenging activity of Phellinus baumii (Phellinus of Hymenochaetaceae) extracts. Food Chem 2003;82:593-7.

37. Lee YR, Woo KS, Kim KJ, Son JR, Jeong HS. Antioxidant activities of ethanol extracts from germinated specialty rough rice. Food Sci Biotechnol 2007;16:765-70.

38. Katalinic V, Milos M, Jukic M. Screening of 70 medicinal plant extracts for antioxidant capacity and total phenols. Food Chem 2006;94:550-7.

39. Tepe B, Sokmen M, Akpulat HA, Sokmen A. In vitro antioxidant activities of the methanol extracts of four Helichrysum species from Turkey. Food Chem 2005;90:685-9.

40. Kumarasamy Y, Byres M, Cox PJ, Jaspars M, Nahar L, Sarker SD, et al. Screening seeds of some Scottish plants for free radical scavenging activity. Phytother Res 2007;21:615-21

41. Karamenderes C, Konyalioglu S, Khan S, Khan IA. Total phenolic contents, free radical scavenging activities and inhibitory effects on the activation of NF-kappa B of eight Centaurea L. Species. Phytother Res 2007;21:488-91.

42. Erasto P, Grierson DS, Afolayan AJ. Evaluation of antioxidant activity and the fatty acid profile of the leaves of Vernonia amygdalina growing in South Africa. Food Chem 2007;104:636-42.

43. Loizzo MR, Said A, Tundis R, Hawas UW, Rashed K, Menichini F, et al. Antioxidant and antiproliferative activity of Diospyros lotus L. Extract and isolated compounds. Plant Foods Hum Nutr 2009;64:264-70.

44. Stanojević L, Stanković M, Nikolić V, Nikolić L, Ristić D, Canadanovic-Brunet J, et al. Antioxidant activity and total phenolic and flavonoid contents of Hieracium pilosella L. Extracts. Sensors (Basel) 2009;9:5702-14.

45. Pukalskas A, Venskutonis PR, Dijkgraaf I, van Beek TA. Isolation, identification and activity of natural antioxidants from costmary (Chrysanthemum balsamita) cultivated in lithuania. Food Chem 2010;122:804-811.

46. Aktumsek A, Zengin G, Guler GO, Cakmak YS, Duran A. Screening for in vitro antioxidant properties and fatty acid profiles of five Centaurea L. species from turkey flora. Food Chem Toxicol 2011;49:2914-20.

47. Suzgec-Selcuk S, Birteksoz AS. Flavonoids of Helichrysum chasmolycicum and its antioxidant and antimicrobial activities. South Afr J Bot 2011;77:170-4

48. Ravisankar N, Sivaraj C, Seeni S, Joseph J, Raaman N. Antioxidant activities and phytochemical analysis of methanol extract of leaves of Hypericum hookerianum. Int J Pharm Pharm Sci 2014;6:456-60.

49. Singh S, Garg V, Yadav D, Beg MN, Sharma N. In vitro antioxidative and antibacterial activities of various parts of Stevia rebaudiana (Bertoni). Int J Pharm Pharm Sci 2012;4:468-73.

50. Duan $\mathrm{X}, \mathrm{Wu} \mathrm{G}$, Jiang Y. Evaluation of antioxidant properties of phenolics from litchi fruit in relation to pericarp browning prevention. Molecules 2007;12:759-71.

51. Wang T, Jonsdottir R, Olafsdottir G. Total phenolic compounds, radical scavenging and metal chelation of extracts from Icelandic seaweeds. Food Chem 2009a; 116:240-8.

52. Gupta AD, Pundeer V, Bande G, Dhar S, Ranganath IR, Kumari GS. Evaluation of antioxidant activity of four folk ant diabetic medicinal plants of India. Pharmacol Online 2009a;1:200-8.

53. Al-Laith AA. Antioxidant components and antioxidant/antiradical activities of desert truffle (Tirmania nivea) from various Middle Eastern origins. J Food Composit Anal 2010;23:15-22. 